\title{
Comparative study of telmisartan and amlodipine to assess the effect on blood pressure, lipid profile and blood glucose level in Indian hypertensive patients
}

\author{
Tripathi $\mathbf{N}^{1}$, Bohara $\mathrm{S}^{2}$, Singh R.R ${ }^{3}$, Kumar $\mathrm{A}^{4}$, Uraiya $\mathrm{D}^{5}$, Dhoan $\mathrm{P}^{6}$ \\ ${ }^{1}$ Dr Neeraj Tripathi, Assistant Professor, Department of Medicine \& ex-junior resident, BRD Medical College, \\ Gorakhpur, ${ }^{2}$ Dr Sangita Bohara, Assistant Professor, Department of Pathology, ${ }^{3}$ Dr R. R. Singh, Associate Professor, \\ Department of Medicine, ${ }^{4}$ Dr Anoop Kumar, Assistant Professor, Department of Medicine, ${ }^{5}$ Dr D.Uraiya, ${ }^{6}$ Dr Pooja \\ Dhoan, Assistant Professor, Department of Medicine; all authors are affiliated with Hind Institute of Medical Sciences, \\ Safedabad, Barabanki, U.P, India.
}

Address for Correspondence: Dr Sangita Bohara, Email: drsangitamamc@ gmail.com

\begin{abstract}
Introduction: Hypertension is emerging as a major health problem and while treating a patient with hypertension it is not only necessary to control blood pressure but also treat the associated risk factors which lead to metabolic syndrome. Methods: A randomized comparative study was designed to evaluate the effect of telmisartan on blood pressure (BP), lipid profile and blood glucose levels in hypertensive patients. This was compared with amlodipine with 1:1 randomisation. $\mathrm{BP}>140 \mathrm{~mm} \mathrm{Hg}$ (systolic) and $>90 \mathrm{~mm} \mathrm{Hg}$ (diastolic) as well as body mass index (BMI) was taken in consideration. Blood sugar levels, lipid profile and urine samples were collected for protein and sugar. These samples were collected at baseline (first visit) and after 6 months. Results: The mean value of systolic BP in telmisartan group decreased from baseline by $17.43 \%(\mathrm{p}<0.001)$ and $13.79 \%$ in diastolic BP $(\mathrm{p}<0.001)$. On comparing with amlodipine, telmisartan reduced mean systolic BP significantly more by $8.42 \%(\mathrm{p}<0.001)$ and $5.59 \%(\mathrm{p}<0.001)$ in diastolic BP. The mean fasting sugar level in patients with telmisartan group after 6 months was $100.70 \mathrm{mg} \%$ which decreased by $10.27 \%$ $(\mathrm{p}<0.01)$ from baseline The effect of post prandial sugar level in telmisartan group was a reduction of $5.57 \mathrm{mg} \%$ from baseline $(\mathrm{p}<0.001)$. There was significant reduction in mean value of urinary protein from $160.22 \mathrm{mg} \%$ to $92.22 \mathrm{mg} \%$ $(\mathrm{p}<0.001)$. Conclusion: Besides significant reduction in BP, telmisartan also had beneficial effects on various metabolic parameters, where amlodipine was not effective. The salutary effects of telmisartan on the metabolic profile may be additional attribute beyond its established antihypertensive effect.
\end{abstract}

Key words: Telmisartan, Amlodipine, Metabolic syndrome, Hypertension, Blood pressure.

\section{Introduction}

Increasing prevalence of hypertension is emerging as a major health problem all over the world. At a very conservative estimate of hypertension prevalence in India is of $20 \%$ in urban and $10 \%$ in rural population, we have 89 million hypertensives in India [1]. Metabolic syndrome is defined by a constellation of interconnected physiological, biochemical, clinical and metabolic factors that directly increases the risk of cardiovascular disease, type 2 diabetes mellitus, and all cause mortality [2].

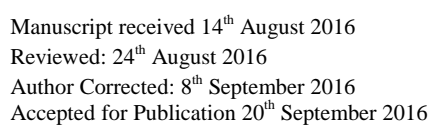

The benefits of treating hypertension have been proved beyond doubt. Antihypertensive therapy is associated with reductions in incidence of stroke by $35 \%-40 \%$, myocardial infarction by $20 \%-25 \%$ and heart failure by more than $50 \%$ [3].

Thus, it appears that while treating a patient with hypertension it is not only necessary to control blood pressure (BP) but also simultaneously to treat these associated risk factors as well. The Saga Telmisartan Aggressive Research (STAR) trial as well as many other studies, claimed that telmisartan also possesses lipid as well as glucose lowering properties. The 
comparison of telmisartan and amlodipine with regards to effects on these properties, have not been done previously in the literature [4-6].

\section{Material and Methods}

The present study is a randomized comparative study, designed to evaluate the effect of telmisartan on blood pressure (BP), lipid profile and blood glucose levels (BGL) in patients with hypertension irrespective of baseline medications being taken.

This effect was compared with amlodipine with 1:1 randomisation. The objective was to assess the BP and metabolic effects of telmisartan in Indian hypertensive population.

The present study was conducted over a period of one academic year in Baba Raghav Das Medical College and associated Nehru Chikitsalaya, Gorakhpur after approval of the ethical committee. Inclusion criteria were age $\geq 40$ years, $\mathrm{BP} \geq 140 \mathrm{~mm} \mathrm{Hg}$ systolic and $\geq 90 \mathrm{~mm} \mathrm{Hg}$ diastolic. This inclusion criterion was followed irrespective of medications the patient has been taking.

Any patient taking other Angiotensin receptor blockers, having serum creatinine $>3 \mathrm{mg} \%$ or creatinine clearance $<30 \mathrm{ml} /$ minute, severe cardiac or cerebrovascular complications, clinically relevant hyperkalemia, bilateral renal artery stenosis or single renal artery stenosis in a solitary kidney was excluded from the study. Pregnant females were also excluded.

The following parameters were observed at the time of entry:

1. BP $>140 \mathrm{~mm} \mathrm{Hg}$ (systolic) and $>90 \mathrm{~mm} \mathrm{Hg}$ (diastolic) irrespective of symptoms.

\section{Results}

The demographic characteristics including the pretreatment values of various study variables of the patients were noted (Table 1). No significant difference was observed in both the groups.

Larger numbers of patients (24 out of 65) dropped out for some reasons compared with Telmisartan group (7 out of 65).

The drop out were not due to drug inefficacy or side effects as inquired by the patients on telephone. In Telmisartan group, the drugs was given as a new isolated prescription in 36 and in rest 22 cases as add on. In Amlodipine group, these figures were 29 and 12 respectively.

Number of patients enrolled in Telmisartan group were 58 with mean age 61.48 years of which, $36(62.06 \%)$ were males and $22(37.93 \%)$ females. The total number of patients included in Amlodipine therapy was 41 with mean of 58.34 years. Among them, $28(68.29 \%)$ were males and 13 females $(31.70 \%)$.
2.General and systemic examination were done including measurements of body weight, height and body mass index (BMI).

Fasting (minimum 12 hours) venous blood samples $(10 \mathrm{ml})$ were obtained for laboratory evaluation of hematology and clinical chemistry parameters including total cholesterol, Low density lipoprotein cholesterol (LDL-C), High density lipoprotein cholesterol (HDLC), triglycerides (TG) and glucose.

Other routine blood investigations like blood samples were obtained for laboratory evaluation of postprandial sugar level. Simultaneously urine samples were collected for biochemical analysis of protein and sugar. These samples were collected at baseline (first visit)

An autoanalyser was used to assay plasma glucose using the hexokinase method, plasma triglycerides using glycerol-3-phopshate-oxidase p-aminophenazone mehod, HDL-C using immunoinhibition. LDL-C was calculated using the Friedewald formula:- LDL-C $=$ TC[HDL-C +TG/5].

Biochemical analysis was done for urinary protein by sulphosalicylic acid method and for sugar by Benedict's method. BP measurements were taken at baseline (at first visit), at regular follow-up visits and after 6 months treatment using cuff sphygmanometry.

Data were collected at baseline and 6 months after the initiation of therapy. Results were reported as mean \pm SD and percentage were calculated. The difference between two means or the reduction in the mean among two group values were compared by $\mathrm{Z}$ test and $\mathrm{p}$ value < 0.05 was taken as significant. and after 6 months. 
Table-1: Patients baseline characteristics.

\begin{tabular}{|c|c|c|c|}
\hline & Values in telmisartan group & Values in amlodipine group & p value \\
\hline Number of patients & 58 & 41 & \\
\hline Male & 36 & 28 & 13 \\
\hline Female & 22 & $58.34 \pm 10.49$ & $>0.05$ \\
\hline Age (years) & $61.48 \pm 9.80$ & $26.48 \pm 5.89$ & $>0.05$ \\
\hline BMI (kg/m $\left.{ }^{2}\right)$ & $25.35 \pm 4.43$ & $155.12 \pm 18.57$ & $>0.05$ \\
\hline Systolic BP (mm Hg) & $157.93 \pm 16.38$ & $100.09 \pm 16.67$ & $>0.05$ \\
\hline Diastolic BP $(\mathrm{mm} \mathrm{Hg)}$ & $98.41 \pm 16.88$ & $177.70 \pm 25.87$ & $>0.05$ \\
\hline Total Cholesterol (mg\%) & $184.91 \pm 27.66$ & $115.17 \pm 29.28$ & $>0.05$ \\
\hline LDL-C (mg\%) & $121.41 \pm 26.91$ & $157.97 \pm 26.84$ & $>0.05$ \\
\hline Triglycerides (mg\%) & $160.0 \pm 16.67$ & $111.07 \pm 24.34$ & $>0.05$ \\
\hline Fasting sugar level (mg\%) & $112.23 \pm 20.41$ & $146.60 \pm 28.99$ & $>0.05$ \\
\hline Post prandial sugar level $(\mathrm{mg} \%)$ & $140.37 \pm 18.52$ & 6 & \\
\hline Diabetes & 7 & 4 & \\
\hline Nephropathy & 5 & 8 & \\
\hline Impaired sugar level & 8 & & \\
\hline
\end{tabular}

The mean body mass index (BMI) in telmisartan group patients was $26.48 \mathrm{~kg} / \mathrm{m}^{2}$. Maximum number of patients were in overweight category $(n=27,46.55 \%)$. The number of patients having normal BMI was 17 . The numbers of obese patients were 9 male patients. The underweight patients were only 5 .

The mean BMI in amlodipine group was $26 \mathrm{~kg} / \mathrm{m} 2$ in males and $26.34 \mathrm{~kg} / \mathrm{m} 2$ in females. Normal BMI and overweight patients were almost same being 17 and 18 respectively. Only 3 male patients in this group included in the obese category.

Out of all 99 patients, 13 were diabetic, comprising 8 males and 5 females. Eight cases were newly diagnosed in the study and the rest were old cases with diabetes. Besides, 4 of the diabetic patient had nephropathy. Impaired glucose levels were seen in 16 patients, of which 9 had impaired fasting sugar level whereas 7 had impaired glucose tolerance (IGT).

Effect of Telmisartan- The mean value of systolic BP in Telmisartan group before therapy was $157 \mathrm{~mm} \mathrm{Hg}$. In 20 patients systolic BP was $\geq 160 \mathrm{~mm} \mathrm{Hg}$. After 6 months, the value was $130.4 \mathrm{~mm} \mathrm{Hg}$ with more than $2 / 3^{\text {rd }}$ patients achieving their goal below $140 \mathrm{~mm} \mathrm{Hg}$. The reduction in total mean value was $17.43 \%$ with $\mathrm{p}$ value $<0.001$.

The mean value of diastolic BP before therapy was $98.41 \pm 16.88 \mathrm{~mm} \mathrm{Hg}$ with maximum number of patients ( $\mathrm{n}=28$ ) having value $>100 \mathrm{~mm} \mathrm{Hg}$. After 6 months, the mean value was $84.84 \pm 11.67 \mathrm{~mm} \mathrm{Hg}$ with change in reduction being $13.78 \%$ ( $p$ value $<0.001$ ). Most of the patients $(n=50,82 \%)$ achieved their goal $<90 \mathrm{~mm} \mathrm{Hg}$. (Table 2).

Before therapy mean fasting blood sugar (FBS) level was $112.23 \mathrm{mg} \%$ with 5 patients had value between $110-126 \mathrm{mg} \%$ (impaired FBS level). After 6 months therapy, the mean level came down to $100.70 \pm 22.32 \mathrm{mg} \%$ with reduction being $11.53 \%$ ( $\mathrm{p}$ value $<0.05$ ).

At the entry of the study post prandial blood sugar(PPBS) level was $140.37 \pm 18.52 \mathrm{mg} \%$ with 3 patients having value between 140-200(IGT). After 6 months, total mean value came down to $132.55 \pm 16.08 \mathrm{mg} \%$ with change in reduction being $7.82 \%$ ( $\mathrm{p}$ value $<0.05$ ). (Table 2 )

The mean total cholesterol level at entry was $184.91 \pm 27.66 \mathrm{mg} \%$. Maximum patients $(\mathrm{n}=36)$ had level below $<199 \mathrm{mg} \%$ while only 9 patients had value in range of 199-238 (borderline high). Only 3 patients had value in high range (>240mg\%). 
Table-2: Effect of telmisartan on Blood Pressure (BP), Blood sugar level and Lipid profile level.

\begin{tabular}{|c|c|c|c|c|}
\hline $\begin{array}{l}\text { Total number of patients } \\
\qquad(n=58)\end{array}$ & $\begin{array}{l}\text { BP Before therapy } \\
\text { Mean } \pm \text { SD } \\
(\mathrm{mm} \mathrm{Hg})\end{array}$ & $\begin{array}{c}\text { BP After } 6 \text { months therapy } \\
\text { Mean } \pm \text { SD } \\
(\mathrm{mm} \mathrm{Hg})\end{array}$ & $\begin{array}{c}\text { Change } \\
(\%) \text { in mean }\end{array}$ & p value \\
\hline Systolic BP & $157.93 \pm 16.38$ & $130.40 \pm 20.22$ & -17.43 & $<0.001$ \\
\hline Diastolic BP & $98.41 \pm 16.88$ & $84.84 \pm 11.67$ & -13.79 & $<0.001$ \\
\hline $\begin{array}{l}\text { Total number of patients } \\
\qquad(n=58)\end{array}$ & $\begin{array}{l}\text { Blood Sugar level } \\
\text { Before therapy } \\
\text { Mean } \pm \text { SD } \\
(\mathrm{mg} \%)\end{array}$ & $\begin{array}{c}\text { Blood Sugar level } \\
\text { After } 6 \text { months therapy } \\
\text { Mean } \pm \text { SD } \\
(\mathrm{mg} \%)\end{array}$ & $\begin{array}{c}\text { Change } \\
(\%) \text { in mean }\end{array}$ & p value \\
\hline Fasting sugar level & $112.23 \pm 20.41$ & $100.70 \pm 22.32$ & -10.27 & $<0.001$ \\
\hline Post prandial sugar level & $140.37 \pm 18.52$ & $132.55 \pm 16.08$ & -5.57 & $<0.001$ \\
\hline Lipid profile $(\mathbf{n}=58)$ & $\begin{array}{c}\text { Before therapy } \\
\text { Mean } \pm \text { SD } \\
(\mathrm{mg} \%)\end{array}$ & $\begin{array}{c}\text { After } 6 \text { months therapy } \\
\text { Mean } \pm \text { SD } \\
(\mathrm{mg} \%)\end{array}$ & $\begin{array}{c}\text { Change } \\
(\%) \text { in mean }\end{array}$ & p value \\
\hline Total Cholesterol & $184.91 \pm 27.66$ & $160.9 \pm 12.76$ & -12.98 & $<0.001$ \\
\hline HDL-C & $45.32 \pm 4.80$ & $45.06 \pm 4.45$ & +0.57 & $>0.05$ \\
\hline LDL-C & $121.41 \pm 26.91$ & $101.25 \pm 10.59$ & -16.60 & $<0.001$ \\
\hline Triglyceride level & $160.0 \pm 16.67$ & $152.12 \pm 18.67$ & -4.92 & $<0.01$ \\
\hline
\end{tabular}

After therapy, total mean came down to $160.9 \pm 12.76 \mathrm{mg} \%$ with change in reduction being $12.98 \%$. No value was in the high range and only 3 patients were borderline high. Level of HDL-C before therapy was $45.32 \pm 4.8 \mathrm{mg} \%$ while after 6 months, it was $45.06 \pm 4.45 \mathrm{mg} \%$. The change was $0.57 \%$ which was not statistically significant. Total mean value of low density cholesterol before therapy was $121.41 \pm 26.91 \mathrm{mg} \%$. Only 10 patients had value in high range, $159-188 \mathrm{mg} \%$. After 6 months of Telmisartan therapy, mean value was $101.25 \pm 10.59 \mathrm{mg} \%$. Maximum number of patients $(\mathrm{n}=32)$ had triglyceride level in borderline high range $149-198 \mathrm{mg} \%$, while in the rest it was in the desirable level of $<150 \mathrm{mg} \%$ with mean value of $130.9 \pm 10.82 \mathrm{mg} \%$. After 6 months, total mean value was $152.12 \pm 18.67 \mathrm{mg} \%$ with change in reduction being $4.92 \%$. (Table-2)

\section{Effect of Amlodipine}

Systolic BP in this group in the beginning was $155.12 \mathrm{~mm} \mathrm{Hg}$. At the end of the study more than $2 / 3^{\text {rd }}$ patients ( $\mathrm{n}=30$ ) achieved their goal below $140 \mathrm{~mm} \mathrm{Hg}$, while the rest had range in between $141-150 \mathrm{~mm} \mathrm{Hg}$. Total mean value was $138.82 \pm 16.51 \mathrm{~mm} \mathrm{Hg}$ with change in reduction of $10.56 \%(\mathrm{p}<0.001)$.

Diastolic BP in this group before therapy was $100.09 \mathrm{~mm} \mathrm{Hg}$. After 6 months, treatment total mean of diastolic BP was $90.43 \pm 14.76 \mathrm{~mm} \mathrm{Hg}$ with more than $2 / 3^{\text {rd }}(\mathrm{n}=26)$ achieving their target value of $<90 \mathrm{~mm} \mathrm{Hg}$. The total change in reduction was about $9.65 \%$ with $\mathrm{p}$ value $<0.001$. (Table- 8 )

Before therapy, mean FBS level was $111.07 \mathrm{mg} \%$ which came down to $109.36 \mathrm{mg} \%$ with change in reduction being $1.54 \%$ after 6 months of therapy (Table 3). Before therapy mean PPBS level was $146.60 \mathrm{mg} \%$ which came down to $144.29 \mathrm{mg} \%$ with change in reduction being $1.58 \%$ after 6 months of therapy. (Table-3)

Before therapy, mean value for total cholesterol was $177.70 \mathrm{mg} \%$ while after 6 months, these values came down to $174.7 \mathrm{mg} \%$ with change in reduction being $1.68 \%$.

The difference was not statistically significant. The LDL-C values were $115.17 \mathrm{mg} \%$ and $118.73 \mathrm{mg} \%$, before and after therapy respectively.

The mean value of triglyceride level was $157.97 \mathrm{mg} \%$ before therapy and $160.0 \mathrm{mg} \%$ after therapy. There was negligible changes in HDL-C levels. The $\mathrm{p}$ value for all of the above changes during studies, were not significant $(>0.05)$. (Table-3) 
Table-3: Effect of amlodipine on Blood Pressure (BP), Blood sugar level and lipid profile.

\begin{tabular}{|c|c|c|c|c|}
\hline $\begin{array}{l}\text { Total number of patients } \\
\qquad(n=41)\end{array}$ & $\begin{array}{l}\text { BP Before therapy } \\
\text { Mean } \pm \text { SD } \\
(\mathrm{mm} \mathrm{Hg})\end{array}$ & $\begin{array}{c}\text { BP After } 6 \text { months therapy } \\
\text { Mean } \pm \text { SD } \\
(\mathrm{mm} \mathrm{Hg})\end{array}$ & $\begin{array}{c}\text { Change } \\
(\%) \text { in mean }\end{array}$ & p value \\
\hline Systolic BP & $155.21 \pm 18.57$ & $138.82 \pm 16.51$ & -10.56 & $<0.001$ \\
\hline Diastolic BP & $100.09 \pm 16.76$ & $90.43 \pm 14.76$ & -9.65 & $<0.001$ \\
\hline $\begin{array}{l}\text { Total number of patients } \\
\qquad(n=41)\end{array}$ & $\begin{array}{l}\text { Blood Sugar level } \\
\text { Before therapy } \\
\text { Mean } \pm \text { SD } \\
(\mathrm{mg} \%)\end{array}$ & $\begin{array}{c}\text { Blood Sugar level } \\
\text { After } 6 \text { months therapy } \\
\text { Mean } \pm \text { SD } \\
(\mathrm{mg} \%)\end{array}$ & $\begin{array}{c}\text { Change } \\
(\%) \text { in mean }\end{array}$ & p value \\
\hline Fasting sugar level & $111.07 \pm 24.34$ & $109.36 \pm 20.81$ & -1.54 & $>0.05$ \\
\hline Post prandial sugar level & $146.60 \pm 28.99$ & $144.29 \pm 26.33$ & -1.58 & $>0.05$ \\
\hline Lipid profile $(n=41)$ & $\begin{array}{l}\text { Before therapy } \\
\text { Mean } \pm \text { SD } \\
(\mathrm{mg} \%)\end{array}$ & $\begin{array}{c}\text { After } 6 \text { months therapy } \\
\text { Mean } \pm \text { SD } \\
(\mathrm{mg} \%)\end{array}$ & $\begin{array}{c}\text { Change } \\
(\%) \text { in mean }\end{array}$ & p value \\
\hline Total Cholesterol & $177.70 \pm 25.87$ & $174.7 \pm 22.51$ & -1.69 & $>0.05$ \\
\hline HDL-C & $43.43 \pm 3.14$ & $43.85 \pm 3.77$ & +0.96 & $>0.05$ \\
\hline LDL-C & $118.73 \pm 22.98$ & $115.17 \pm 29.28$ & -3.00 & $>0.05$ \\
\hline Triglyceride level & $160.0 \pm 21.86$ & $157.97 \pm 26.84$ & -1.27 & $>0.05$ \\
\hline
\end{tabular}

Comparison between Telmisartan and Amlodipine group- On comparing both the drugs on the basis of various study variables, significant differences were observed not only in systolic and diastolic BP levels but in fasting and post prandial blood glucose levels, total and LDL cholesterol and triglyceride level as well. (Table-4).

Table-4: Comparison between telmisartan and amlodipine group.

\begin{tabular}{|c|c|c|c|c|}
\hline & Telmisartan group $(n=58)$ & $\begin{array}{c}\text { Amlodipine group } \\
(n=41)\end{array}$ & Change in mean & p value \\
\hline & $\begin{array}{c}\text { Mean } \pm \text { SD } \\
\text { (after } 6 \text { months) }\end{array}$ & $\begin{array}{c}\text { Mean } \pm \text { SD } \\
\text { (after } 6 \text { months) }\end{array}$ & & \\
\hline Systolic BP (mm Hg) & $130.40 \pm 20.22$ & $138.82 \pm 16.51$ & 6.46 & $<0.001$ \\
\hline Diastolic BP (mm Hg) & $84.84 \pm 11.67$ & $90.43 \pm 14.76$ & 6.59 & $<0.001$ \\
\hline Fasting sugar level (mg\%) & $100.70 \pm 22.32$ & $109.36 \pm 20.81$ & 8.66 & $<0.01$ \\
\hline Post prandial sugar level (mg\%) & $132.55 \pm 21.08$ & $144.29 \pm 26.33$ & 11.74 & $<0.01$ \\
\hline Total cholesterol (mg\%) & $160.90 \pm 12.76$ & $174.70 \pm 22.51$ & 13.8 & $<0.001$ \\
\hline LDL-C (mg\%) & $101.25 \pm 10.59$ & $118.73 \pm 22.86$ & 17.48 & $<0.001$ \\
\hline Triglyceride $(\mathrm{mg} \%)$ & $152.12 \pm 21.67$ & $160 \pm 21.86$ & 7.88 & $<0.01$ \\
\hline
\end{tabular}

\section{Discussion}

From previous studies, telmisartan is approved for the treatment of hypertension, ether as monotherapy or in combination with other antihypertensive drugs. Several studies have reported the additional beneficial effects on the various parameters of the metabolic syndrome, like lowering of blood glucose levels and lipid values. This may be attributed to the fact that it also acts as a partial peroxisome proliferators activated receptor-gamma (PPAR- $\gamma$ ) agonist, a well known target for antidiabetic and antiobesity drugs [7,8].
The present study was planned to see the effects of telmisartan on blood pressure as well as in Indian hypertensive population and compared with the effects of another antihypertensive drug, amlodipine. It was used as a control because its efficacy as an antihypertensive is well established by several studies [9] and mega trials [10] as well as it is widely used as standard treatment in hypertension. The total number of patients followed in our study was 99 with a male to female ratio of 1.82:1. The lesser number of female 
patients in the present study was probably due to the fact that the female patients utilize medical facility less often in the Indian set up. The number of drop out was more in Amlodipine group (24 patients) compared with Telmisartan group ( 7 patients). The cause for this difference was not known but apparently most of the patients were from far off distances and therefore, dropped out of the study due to their inability to come to the outpatient department repeatedly.

The mean age of the patient in the present study was 62.57 years while it was higher in the STAR trial (69 years) [4]. The majority of the patients $(n=57)$ were in 40-60 year age group. The mean age of the total males was 59.76 years while 60.73 years in females.

The mean BMI in the present study was $25.09 \mathrm{~kg} / \mathrm{m} 2$. The maximum number of patients $(n=45)$ were in overweight category while 34 patients had normal BMI. In overweight patients, more than half $(n=26)$ were between $40-50$ years.

In the present study, both the drugs were started in low dose and up titrated gradually to maximum of $80 \mathrm{mg}$ and 10mg in Telmisartan and Amlodipine respectively. This was also done in STAR trial [4], however, in another study by Vitale et al [11], Telmisartan was started with fixed maximum dose of $80 \mathrm{mg}$.

Similar to STAR trial [4] we have excluded patients with serious complications and critical illnesses like Coronary artery disease, Congestive heart failure, cerebrovascular accidents, etc. Out of the 99 patients, $13(13.13 \%)$ were diabetic comprising 8 males and 5 females. Eight cases were newly diagnosed at the time of entry and the rest were known cases of diabetes. Rest of the patients with nephropathy were related to hypertension. Impaired glucose levels were seen in 16 patients, out of which 9 had impaired fasting glucose level whereas 7 had impaired glucose tolerance.

During study period, no patient was advised life style modifications and diet habit changes. Known diabetics were on oral hypoglycaemic agents including metformin, glimipride and pioglitazone, either singly or in combinations, but no patient was on insulin. Blood sugar levels were well controlled in known diabetics $(n=5)$.

The mean of systolic BP was $155.44 \mathrm{~mm} \mathrm{Hg}$ and diastolic BP was $98.33 \mathrm{~mm} \mathrm{Hg}$. In STAR trial [4], these values were $159 \mathrm{~mm} \mathrm{Hg}$ and $87 \mathrm{~mm} \mathrm{Hg}$ respectively. The mean value of systolic BP in overweight and obese patients $(\mathrm{n}=55)$ was $162 \mathrm{~mm} \mathrm{Hg}$ and diastolic BP was $100 \mathrm{~mm} \mathrm{Hg}$. In patients with normal BMI, mean systolic and diastolic BP was $150 \mathrm{~mm} \mathrm{Hg}$ and $88 \mathrm{~mm} \mathrm{Hg}$ respectively. This difference in blood pressure was significant $(<0.001)$ suggesting that overweight and obese patients have higher blood pressure levels than non obese persons.

In the present study, combined hyperlipidemia was less common than isolated single lipid abnormality, 10 patients had combined lipid elevated patterns (triglycerides > 200mg\%, LDL-C $\geq 130 \mathrm{mg} \%$ ) the remaining $(\mathrm{n}=18)$ had other predominant lipid patterns. The mean value of LDL-C was $118.40 \mathrm{mg} \%$ and $158.43 \mathrm{mg} \%$ for triglycerides. In STAR trial, LDL-C was $122 \mathrm{mg} \%$ and $\mathrm{TG}$ was $141 \mathrm{mg} \%$. In diabetic patients $(\mathrm{n}=13)$, mean values of LDL-C and TG were $146.76 \mathrm{mg} \%$ and $172 \mathrm{mg}$ respectively [4].

In patients with $\mathrm{BP} \geq 160 \mathrm{mmHg} \quad(\mathrm{n}=34)$, mean value of LDL-C was $130.22 \mathrm{mg} \%$ in comparison to patients with systolic $\mathrm{BP}<160 \mathrm{~mm} \mathrm{Hg}$, which was $116.22 \mathrm{mg} \%$ ( $p$ value $<0.001)$. In overweight persons $(n=40)$, it was $136.77 \mathrm{mmHg}$ and $120.88 \mathrm{~mm} \mathrm{Hg}$ in normal BMI patients $(\mathrm{p}<0.001)$. Hence, dyslipidemia was found to be more common in higher BMI persons.

In the present study, total mean value of fasting blood sugar level was $112.24 \mathrm{mg} \%$. The reported value in STAR trial [4] was $108 \mathrm{mg} \%$. Impaired glucose patterns were seen in 16 patients of which, 9 had impaired fasting glucose tolerance. In diabetic patients $(n=13)$, mean fasting sugar level was $110.24 \mathrm{mg} \%$ and mean post prandial sugar level was $146.22 \mathrm{mg} \%$. In known diabetic patients on OHA, drugs were not changed and in the newly diagnosed diabetic patients, OHA were not prescribed as well as patients in both groups were not given statins. This was intentionally done to observe additional effect of the study drugs.

Comparison of telmisartan $\&$ amlodipine- The mean value of systolic BP in telmisartan group decreased from baseline by $17.43 \%(p<0.001)$ and $13.79 \%$ in diastolic BP $(\mathrm{p}<0.001)$. This finding is similar to a previous study (STAR trial) [4], while it was significant $\mathrm{p}<0.05$ in another study by Vitale et al [11]. This change was uniformly distributed among all age groups and in both sexes. The changes in BP in amlodipine were also highly significant $(\mathrm{p}<0.001)$, which reduced systolic BP 
from baseline by $10.56 \%$ and $9.65 \%$ in diastolic pressure. It was also not affected by age and sex distribution. On comparing both the drugs, telmisartan reduced mean systolic BP significantly more by $8.42 \%$ $(\mathrm{p}<0.001)$ and $5.59 \%(\mathrm{p}<0.001)$ in diastolic BP.

Previous studies [12] support that telmisartan exerts sustained and more effective BP control over 24 hours including the critical last 6 hours of the morning.

Both the drugs were effective in reducing BP significantly. However, on comparison, telmisartan proved more effective. In another study (ASCOT) [9], it was shown that amlodipine/perindopril (ACE inhibitor) based regimen lowered systolic BP by $2.7 \mathrm{~mm} \mathrm{Hg}$ more than atenolol/bendroflumethazide based regimen.

There are very few studies available regarding the effect of Angiotensin receptor blockers (telmisartan) on the metabolic parameters. In the present study, the mean fasting sugar level in patients with telmisartan group after 6 months was $100.70 \mathrm{mg} \%$ which decreased by $10.27 \%(\mathrm{p}<0.01)$ from baseline. In study by Vitale et al [11], this reduction was $8.3 \%(\mathrm{p}<0.05)$. The change was more striking in diabetics and in patients with impaired glucose levels. Their combined mean was $116.28 \mathrm{mg} \%$ compared with non diabetic patients, with mean value $100.20 \mathrm{mg} \%$. The above combined mean value decreased by $10.30 \%$ from baseline $(\mathrm{p}<0.001)$ which is highly significant. This fact was also supported in STAR trial [4] where FBG, significantly decreased in patients with $\mathrm{FBG} \geq 110 \mathrm{mg} \%(20 \%, \mathrm{p}<0.05)$.

The effect of post prandial sugar level in telmisartan group was also significant. Reduction was being $5.57 \mathrm{mg} \%$ from baseline $(\mathrm{p}<0.001)$. In study by Vitale et al [11], reduction was about $13.2 \%(\mathrm{p}<0.01)$.

In the STAR trial [4], effect on post prandial sugar level was not observed. In combined patients (diabetic and IGT), value was reduced by $16 \%$ from baseline $(p<0.001)$, which was more than non-diabetic patients. This observation leads to the conclusion that the effect of telmisartan is more marked on higher sugar levels.

In the ASCOT-BPLA trial [9] it was shown that amlodipine based regimen induced less diabetes (metabolic syndrome) than the atenolol based regimen. In the present study, the effect of amlodipine on sugar level was not significant ( $p>0.05$ ). In telmisartan group, the mean value of LDL-C after 6 months was
$101.25 \mathrm{mg} \%$ which reduced from baseline by $16.60 \%$ $(\mathrm{p}<0.001)$. In previous study (STAR trial) [4] the reduction was $11 \%(\mathrm{p}<0.01)$. In diabetic patients $(\mathrm{n}=7)$, the mean value was $136.30 \mathrm{mg} \%$, which came down to $110.30 \mathrm{mg} \% \quad(\mathrm{p}<0.001)$ in comparison with non diabetics, where reduction was $11.3 \%(\mathrm{p}<0.05)$. The mean value of triglyceride was decreased to $152.2 \mathrm{mg} \%$, with reduction of $7.88 \%(\mathrm{p}<0.01)$.

The reduction was more in diabetic patients, where reduction was $12.66 \%(\mathrm{p}<0.001)$. In the STAR trial, there was significant decrease in TG in patients with $\geq 150 \mathrm{mg} \%$ (270 to $175 \mathrm{mg} \%, \mathrm{p}<0.005$ ). This difference in reduction in the present study was apparent due to larger numbers of the patients having $\mathrm{TG} \geq 150 \mathrm{mg} \%$. In another study by Derosa et al [13] also showed similar results in a 12 month study that compared telmisartan with nifedipine gastrointestinal therapeutic system.

The mechanism of TC and LDL-C lowering in response to telmisartan is not well understood. Dormondy JA et al [14], have shown that, since a direct PPAR- $\gamma$ agonist, pioglitazone, does not affect TC and LDL-C levels, it may be independent of PPAR- $\gamma$ activation [14].

In contrast more recently, it has been shown that a high dose telmisartan has a PPAR- $\gamma$ action that leads to lowering of TC and LDL-C levels through influx of remnant lipoprotein into the liver [5]. The effect of amlodipine on lipid profile was not significant $(\mathrm{p}<0.05)$.

In the present study, total patients with nephropathy were 9 of which 4 were diabetic. The mean value of serum creatinine was 1.78 . Five cases were in telmisartan group. During study, it was observed that there was significant reduction in mean value of urinary protein from $160.22 \mathrm{mg} \%$ to $92.22 \mathrm{mg} \%$ ( $\mathrm{p}<0.001)$. The mean value of serum creatinine after 6 months 1.60. In a previous study (AMADEO) [15], mean change in urinary protein-creatinine ratio after one year of treatment was better with telmisartan $(\mathrm{p}=0.0283)$. The RENAAL study [16] observed that angiotensin receptor blockers reduce proteinuria, the time of creatinine doubling and slow the progression of renal disease independent of the changes in BP. This renoprotective effect was not shown in amlodipine group.

\section{Conclusion}

Telmisartan and Amlodipine both reduced BP significantly in most of the patients studied. Telmisartan also had beneficial effects on various metabolic 
parameters, where amlodipine was not effective. It reduced blood sugar levels and lipid variables significantly especially in hyperglycaemic and hyperlipidemic patients. It significantly reduced proteinuria in patients with nephropathy. The present study suggests that salutary effects of telmisartan on the metabolic profile may be additional attribute beyond its established antihypertensive effect, which can be useful particularly in the treatment of metabolic syndrome.

Funding: Nil, Conflict of interest: None initiated, Permission from IRB: Yes

\section{References}

1. Anand MP. Epidemiology of hypertension India. Indian Heart J. 2010 Sep-Oct;62(5):388-93.

2. Kaur J. A comprehensive review on metabolic syndrome. Cardiol Res Pract. 2014;2014:943162. doi: 10.1155/ 2014/943162. Epub 2014 Mar 11.

3. Chobanian AV, Bakris GL, Black HR, Cushman WC, Green LA, Izzo Jr JL, Jones DW, Materson BJ, Oparil S, Wright Jr JT, Roccella EJ. The seventh report of the joint national committee on prevention, detection, evaluation, and treatment of high blood pressure: the JNC 7 report. Jama. 2003 May 21;289(19):2560-71.

4. Inoue T, Morooka T, Moroe K, Ikeda H, Node $\mathrm{K}$. Effect of telmisartan on cholesterol levels in patients with hypertension - Saga Telmisartan Aggressive Research (STAR). Horm Metab Res. 2007 May; 39 (5): 372-6.

5. Benson SC, Pershadsingh HA, Ho CI, Chittiboyina A, Desai P, Pravenec M, Qi N, Wang J, Avery MA, Kurtz TW. Identification of telmisartan as a unique angiotensin II receptor antagonist with selective PPAR $\gamma$-modulating activity. Hypertension. 2004 May 1; 43 (5) :993-1002.

6. Schupp M, Janke J, Clasen R, Unger T, Kintscher U. Angiotensin type 1 receptor blockers induce peroxisome proliferator-activated receptor- $\gamma$ activity. Circulation. 2004 May 4;109(17):2054-7.

7. Gress TW, Nieto FJ, Shahar E, Wofford MR, Brancati FL. Hypertension and antihypertensive therapy as risk factors for type 2 diabetes mellitus. Atherosclerosis Risk in Communities Study. N Engl J Med. 2000 Mar 30;342(13):905-12.
8. Isomaa BO, Almgren P, Tuomi T, Forsén B, Lahti K, Nissén M, Taskinen MR, Groop L. Cardiovascular morbidity and mortality associated with the metabolic syndrome. Diabetes care. 2001 Apr 1;24(4):683-9.

9. Dahlof B, Sever PS, Ponter NR. Prevention of cardiovascular events with an antihypertensive regimen of amlodipine adding perindopril as required versus atenolol adding bendroflumethazide as required, in the Ansloscandinavian cardiac outcomes trial-blood pressure lowering arm (ASCOT-BPLA): a multicentre randomized controlled trial. Lancet 2005;366:895-906.

10. ALLHAT Officers and Coordinators for the ALLHAT Collaborative Research Group. The Antihypertensive and Lipid-Lowering Treatment to Prevent Heart Attack Trial. Major outcomes in high-risk hypertensive patients randomized to angiotensinconverting enzyme inhibitor or calcium channel blocker vs diuretic: The Antihypertensive and Lipid-Lowering Treatment to Prevent Heart Attack Trial (ALLHAT). JAMA. 2002 Dec 18;288(23):2981-97.

11. Vitale C, Mercuro G, Castiglioni C, Cornoldi A, Tulli A, Fini M, Volterrani M, Rosano GM. Metabolic effect of telmisartan and losartan in hypertensive patients with metabolic syndrome. Cardiovasc Diabetol. 2005 May 15;4:6.

12. Lacourcière Y, Krzesinski JM, White WB, Davidai G, Schumacher H. Sustained antihypertensive activity of telmisartan compared with valsartan. Blood Press Monit. 2004 Aug;9(4):203-10.

13. Derosa G, Cicero AF, Bertone G, Piccinni MN, Fogari E, Ciccarelli L, Fogari R. Comparison of the effects of telmisartan and nifedipine gastrointestinal therapeutic system on blood pressure control, glucose metabolism, and the lipid profile in patients with type 2 diabetes mellitus and mild hypertension: a 12-month, randomized, double-blind study. Clin Ther. 2004 Aug; 26(8):1228-36.

14. Dormandy JA, Charbonnel B, Eckland DJ, Erdmann E, Massi-Benedetti M, Moules IK, Skene AM, Tan MH, Lefèbvre PJ, Murray GD, Standl E, Wilcox RG, Wilhelmsen L, Betteridge J, Birkeland K, Golay A, Heine RJ, Korányi L, Laakso M, Mokán M, Norkus A, Pirags V, Podar T, Scheen A, Scherbaum W, Schernthaner G, Schmitz O, Skrha J, Smith U, Taton J; PROactive Investigators. Secondary prevention of 
macrovascular events in patients with type 2 diabetes in the PROactive Study (PROspective pioglitAzone Clinical Trial In macroVascular Events): a randomised controlled trial. Lancet. 2005 Oct 8;366(9493):1279-89.

15. Bakris G, Burgess E, Weir M, Davidai G, Koval S; AMADEO Study Investigators. Telmisartan is more effective than losartan in reducing proteinuria in patients with diabetic nephropathy. Kidney Int. 2008
Aug;74(3):364-9. doi: 10.1038/ki.2008.204. Epub 2008 May 21.

16. Lewis EJ, Hunsicker LG, Clarke WR, Berl T, Pohl MA, Lewis JB, Ritz E, Atkins RC, Rohde R, Raz I; Collaborative Study Group. Renoprotective effect of the angiotensin-receptor antagonist irbesartan in patients with nephropathy due to type 2 diabetes. N Engl J Med. 2001 Sep 20;345(12):851-60.

\section{How to cite this article?}

Tripathi N, Bohara S, Singh R.R, Kumar A, Uraiya D, Dhoan P. Comparative study of telmisartan and amlodipine to assess the effect on blood pressure, lipid profile and blood glucose level in Indian hypertensive patients. Int $J$ Med Res Rev 2016;4(9):1693-1701.doi:10.17511/ijmrr. 2016.109.30. 